\title{
Russian claims first in magnetic imaging
}

Bryon MacWilliams, Moscow

At the height of the cold war, Vladislav Ivanov was a young lieutenant in the Red Army charged with trying to use nuclear magnetic resonance in water to help with aircraft navigation.

The days were long and lonely at his radar station, Ivanov recalls, and he had plenty of time to think. Time enough, according to documents filed in 1960 with the USSR State Committee for Inventions and Discovery at St Petersburg, to think of the idea of using magnetic resonance to study the inside of the human body.

"I figured that, because a person is made up primarily of water, the same method could be used in research on living organisms," Ivanov says. "The water inside a person could be used to give a signal showing what exists, or is located, inside."

This concept - magnetic resonance imaging $(\mathrm{MRI})$ - was recognized in October when Paul Lauterbur of the University of Illinois, Urbana-Champaign, and Peter Mansfield of the University of Nottingham, UK, shared the 2003 Nobel Prize in Physiology or Medicine. Ivanov lays no claim to a share in the prize: his ideas stagnated after his seniors rejected them as unviable.

Still, he chuckles at the public protests of Raymond Damadian, a New York-based physician who claims to have thought of the idea first (see Nature 425, 648; 2003).

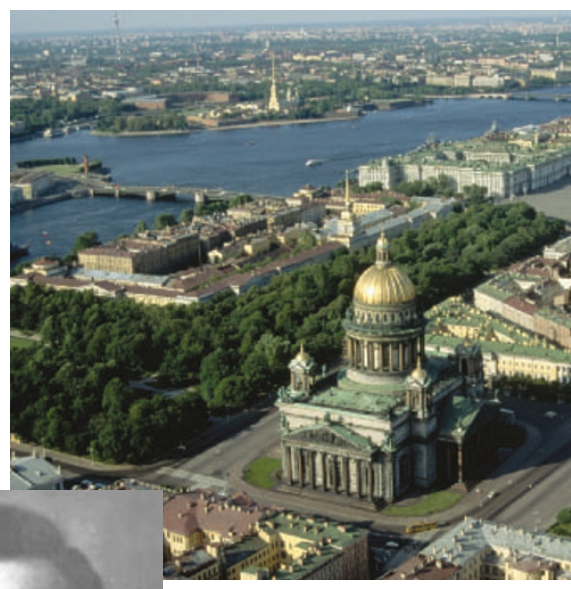

Vladislav Ivanov's ideas for magnetic resonance imaging were hampered by bureaucracy in St Petersburg.

Damadian, whose work was published in 1971, believes that he should share the prize with the physicists. "If I had never been born, there would never be MRI today," Damadian said after the prize was announced.

"I know Damadian's work, but at this point there's nothing that can be done," Ivanov said last week in his office at the St Petersburg State Institute of Fine Mechanics and Optics. "Besides, there are always mistakes when you have major advances in science. You can't keep an idea in one place. They have their own momentum," he adds.
In Ivanov's case, the momentum was quashed by the state committee in St Petersburg, whose records show that Ivanov submitted an application, "Method of examination of the internal structure of material bodies", in 1960.

The application defined Ivanov's principles in detail, and included a diagram of a device identified as MRI equipment. The document was assigned the number $659411 / 26$, and was forwarded for review to scientific institutes in St Petersburg, then known as Leningrad.

"The committee members thought about it, and couldn't figure it out themselves, so they sent it to a critic, who came out sarcastically against it, then sent it to his boss, who signed off on it," Ivanov recalls. "They thought I was mistaken, but I wasn't."

His options for appeal were limited: Red Army officers could not publish abroad. "After that they even started to spy on me, my commander and everyone else to whom I turned for help. They decided I wasn't doing my job, that I had a lot of free time."

Years later, when the work of Lauterbur and Mansfield came to the world's attention, the committee revisited Ivanov's application and gave its assent. But by then, Ivanov says, Soviet science had fallen too far behind.

Today, all he has to show for his ideas is an MRI machine, based on his own ideas, on which he trains students in his lab. "On one hand, the Cold War is guilty. But it was never so cold that it was impossible to do at least something."

\section{US on sidelines as China prepares for satellite launch}

\section{Tony Reichhardt, Washington}

The first of two Chinese Double Star satellites is set to launch next month, marking the most ambitious scientific mission yet for the nation's space programme.

But while European researchers are vigorously engaged in the mission, which will explore the interaction of the solar wind with Earth's magnetosphere, their American colleagues are staying on the sidelines - highlighting a rift between the world's largest space power and its fastest-growing rival.

The first 660-kilogram Double Star satellite is scheduled to reach orbit on 28 December, and its twin will blast off next June. Data on high-energy particles and magnetic fields returned by the spacecraft will supplement information from four European/US Cluster satellites that are already in orbit.
The European Space Agency (ESA) has spent $€ 8$ million (US\$9.5 million) on half of the $\mathbf{1 6}$ scientific instruments on board the two satellites (see Nature 412, 106; 2001).

Some 75 US scientists received NASA funding to participate in the joint Cluster mission. But when China asked ESA to participate in Double Star in 1999, it did not extend the invitation to NASA. As a result, although seven of the eight European instruments on board are duplicates of Cluster instruments, only a dozen or so US scientists will participate as informal members of ESA teams.

In some cases, Cluster instrument components that had been built in the United States had to be manufactured in Europe for Double Star, to get around US regulations restricting the export of technology with possible military application, such as radiation-hardened parts (see Nature 416, 572; 2002).
Solar-terrestrial space research has traditionally been a strong area of cooperation between NASA and ESA. NASA's upcoming ventures in the field, such as the Solar Terrestrial Relations Observatory (STEREO) and the Magnetospheric Multiscale Mission, will still involve international partners, but not as many as before. And the export regulations - officially known as ITAR (International Traffic in Arms Regulations) - have caused further complications.

Mario Acuña, a space scientist at NASA's Goddard Space Flight Center in Greenbelt, Maryland, and an investigator on STEREO, says: "We made it so difficult for Europeans to collaborate with us that we have become a pain that nobody wants to deal with... Every presentation has to be cleared, and the non-US scientists have to have separate meetings. It's an insult to them." 